\title{
Prognostic and clinicopathologic significance of neutrophil-to-lymphocyte ratio in esophageal squamous cell carcinoma: evidence from a meta-analysis
}

\author{
This article was published in the following Dove Press journal: \\ OncoTargets and Therapy \\ 23 February 2017 \\ Number of times this article has been viewed
}

\section{Yu Huang \\ Yue Sun \\ Ping Peng \\ Sixian Zhu \\ Wei Sun \\ Peng Zhang}

Department of Oncology, Tongji Hospital, Tongji Medical College, Huazhong University of Science and Technology, Wuhan, People's Republic of China
Correspondence: Peng Zhang Department of Oncology, Tongji Hospital, Tongji Medical College, Huazhong University of Science and Technology, No 1095 Jie Fang Avenue, Hankou, Wuhan 430030, People's Republic of China

Tel +862783663405

Fax +862783662834

Email pengzhang@tjh.tjmu.edu.cn
Purpose: Evidence from an increasing number of studies has demonstrated that the neutrophil-to-lymphocyte ratio (NLR) is a prognostic factor for various cancers. However, it is unclear whether NLR predicts prognosis in esophageal squamous cell carcinoma (ESCC). We conducted a meta-analysis to investigate the prognostic and clinicopathologic significance of NLR in patients with ESCC.

Patients and methods: Selected studies were identified by searches in PubMed, Embase, and Web of Science databases and filtered using our prepared criteria. The hazard ratio (HR) and odds ratio were chosen as effect measures to assess the prognostic role of NLR and its clinicopathologic significance in ESCC. In total, nine studies containing 2,513 patients were enrolled.

Results: We demonstrated that elevated NLR was associated with worse overall survival in ESCC patients (pooled HR $=1.314 ; 95 \%$ confidence interval, 1.164-1.484; $P<0.001$ ). Elevated NLR was also associated with unfavorable characteristics regarding depth of tumor invasion, tumor size, clinical stage, and differentiation degree.

Conclusion: The results of our meta-analysis suggest that a high NLR value might represent a poor prognosis and worse clinicopathologic characteristics for patients with ESCC.

Keywords: ESCC, NLR, prognosis, meta-analysis, inflammation

\section{Introduction}

Esophageal cancer has a high incidence and a low 5-year survival rate. According to the latest Global Cancer Statistics, esophageal cancer is the seventh most prevalent and sixth highly mortal human cancer in male. In case of female, it is the ninth most common cause of mortality. An estimated 455,800 new esophageal cancer cases and 400,200 deaths occur globally per year. ${ }^{1}$ Esophageal squamous cell carcinoma (ESCC) is the most common histologic subtype, especially in Asian countries. Despite intensive therapies, the prognosis of ESCC remains poor. In patients treated with radical surgical intervention, the reported 5-year survival rate remained about $30 \% .^{2-4}$ Various prognostic factors including tumor stage and genetic polymorphism have been reported, ${ }^{3,4}$ and more recently, certain serum biomarkers, such as inflammation factors, were also suggested to have predictive potential. Such biomarkers are easily assessable and provide important information for clinicians regarding preventive and therapeutic strategies for ESCC patients. ${ }^{5-7}$ 
Inflammatory reactions play a significant role in the occurrence and development of cancer. ${ }^{8-10}$ Levels of inflammation factors, such as neutrophils and C-reactive protein, have been reported to be elevated in many cancers. ${ }^{11-13}$ The neutrophil-to-lymphocyte ratio (NLR), calculated as serum neutrophil counts divided by serum lymphocyte counts, is a common indicator of inflammation. This index was proven to be a significant prognostic factor in many cancers, including colorectal cancer, gastric cancer, and lung cancer. ${ }^{14-16}$ Accumulated data also suggested that elevated NLR was associated with poor prognosis in ESCC patients. ${ }^{17}$ However, some research failed to confirm the NLR as a significant predictor, and the result concerning the prognostic value of NLR in ESCC is still controversial. ${ }^{18}$ Therefore, it was essential to perform a meta-analysis to confirm the effect of NLR on the prognosis of ESCC. Here, we assessed the prognostic value of increased NLR in ESCC using a meta-analysis and analyzed the relationship between NLR and clinicopathologic features in patients with ESCC.

\section{Methods}

\section{Search method}

We searched three major databases, PubMed, Embase, and Web of Science, for all relevant studies. Search items were as follows: "Prognosis" ("Prognoses", "prognostic", "survival”), NLR ("neutrophil lymphocyte ratio", "neutrophil to lymphocyte ratio", "neutrophil-to-lymphocyte ratio"), and ESCC ("Esophageal Neoplasm", "Esophageal cancer", "Esophageal carcinoma", "Esophageal squamous cell carcinoma"). The cutoff date for the search was September 1, 2016.

\section{Inclusion and exclusion criteria}

Studies were selected for inclusion in the meta-analysis according to the following criteria: 1) pretreatment NLR (baseline NLR) was measured from serum; 2) all included patients were diagnosed with ESCC by pathology and did not have any other tumor subtypes; and 3) correlation of NLR with overall survival (OS) was studied. Exclusion criteria were as follows: 1) studies were reviews, letters, abstracts, case reports, or nonclinical types; 2) hazard ratio (HR) and 95\% confidence interval (CI) were not included or could not be calculated; 3) studies were not written in English; and 4) studies reported HRs based on continuous NLR without a clear cutoff point.

\section{Data extraction and quality evaluation}

Two authors (YH and SXZ) evaluated and extracted all candidate studies independently. The full text was examined if the study could not be categorized by its title or abstract.
If the authors failed to reach a consensus, outstanding disagreements were resolved through discussion with a third author (YS). Information on the authors, year of publication, country, study design, study period, number of participants, sex, mean age, cutoff values for NLR, treatment strategy, and HR with $95 \%$ CI was obtained from selected studies for the meta-analysis. NLR was calculated from complete blood counts by dividing the absolute neutrophil count by the absolute lymphocyte count. To ensure study quality, two reviewers (PP and WS) assessed the included studies using the Newcastle-Ottawa Scale (NOS).${ }^{19}$ Studies with NOS scores $\geq 6$ were considered high-quality research.

\section{Statistical analysis}

HR and 95\% CI for OS, disease-free survival (DFS), and progression-free survival (PFS) were either obtained directly from each published study or calculated from the data provided. If univariate and multivariate analyses were both reported in the same study, multivariate-adjusted HRs and their corresponding standard errors were used for the metaanalysis. Odds ratios (ORs) and 95\% CIs were used to evaluate the relationship between NLR and clinicopathologic factors. We measured heterogeneity using $\chi^{2}$-based $Q$ test and Higgins' $I^{2}$ statistic. We applied the fixed-effects model (MantelHaenszel method) when the $P$-value for $Q$ test was $>0.10$ or $I^{2}$ was $<50 \%$, suggesting no significant heterogeneity. We chose the random-effects model (DerSimonian-Laird method) for cases with $P<0.10$ for $Q$ test or $I^{2}>50 \%$. We used subgroup analysis to explore possible heterogeneity among different results. Sensitivity analyses were performed to confirm the robustness of the study. Egger's linear regression test and Begg's funnel plot test were used to assess the publication bias. Differences were considered statistically significant for $P$-values $<0.05$.

\section{Results}

\section{Study characteristics}

A total of 110 studies were selected from the databases after discarding duplicates, and 89 of these studies were excluded after browsing the titles and abstracts. The full texts of the remaining 21 studies were further reviewed, and 12 studies were excluded for the following reasons: one study performed survival analysis using a continuous NLR level and did not describe a clear cutoff value for NLR; two studies used data with a repeated population; three studies were not related to OS; four studies contained patients who were pathologically diagnosed with adenocarcinoma or other tumor subtypes; and two studies did not report the association with survival. The detailed selection processes are shown in Figure 1. 


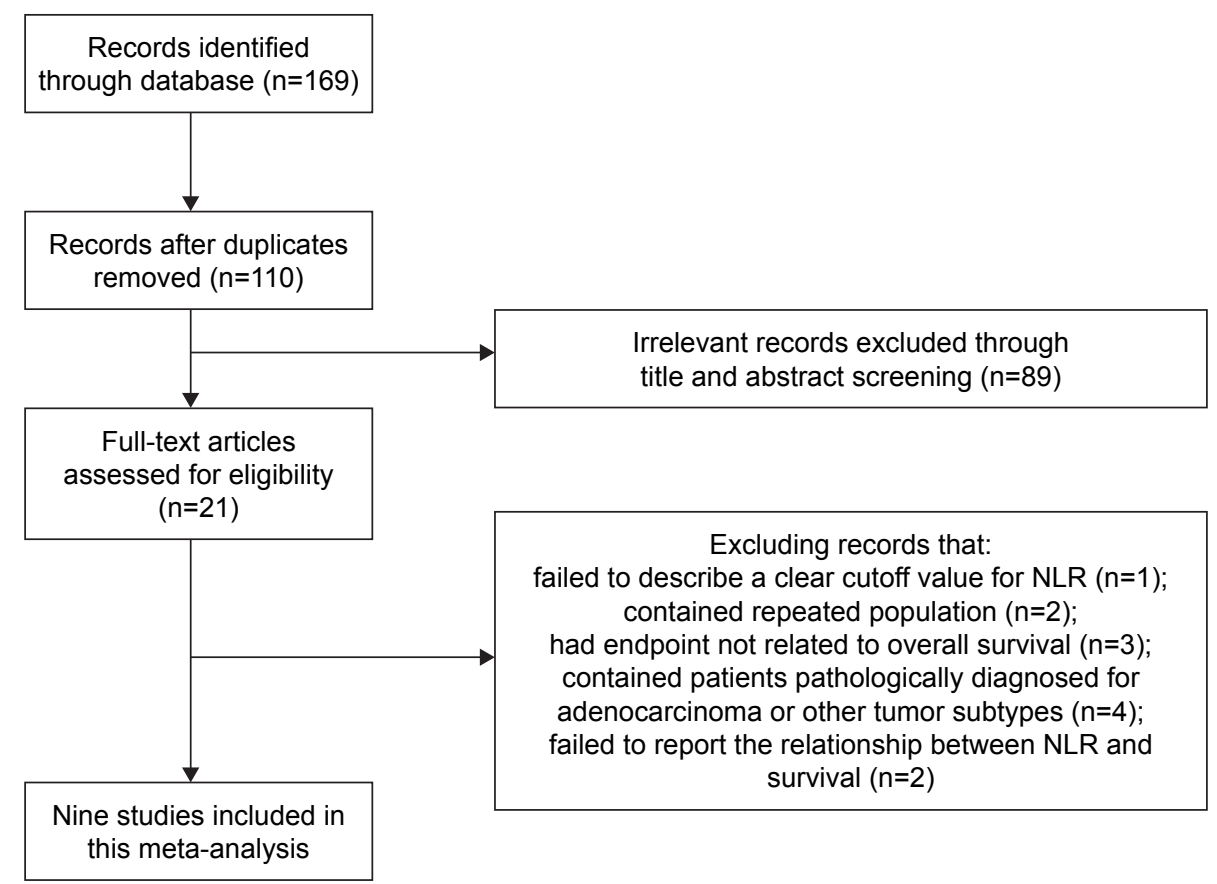

Figure I The flow diagram of the included studies.

Abbreviation: NLR, neutrophil-to-lymphocyte ratio.

In total, nine studies ${ }^{6,7,17,18,20-24}$ were finally enrolled, and 2,513 ESCC patients were included in the meta-analysis. The studies were all from Asian countries (China: $n=6$; Japan: $\mathrm{n}=3$ ). Six studies recruited $<300$ patients, and three studies involved $>300$ patients. NLR cutoff values presented in these studies varied, ranging from 1.7 to 3.612 . Six studies had a cutoff value $>2.5$, and three studies used a value $\leq 2.5$.
Detailed information on the selected studies is summarized in Table 1. All of the research studies had an NOS score $\geq 6$.

\section{NLR and OS in ESCC}

Nine studies with 2,513 ESCC patients reported the association between elevated NLR and OS. We found that high NLR was positively associated with poor OS (pooled

Table I Main characteristics of all the studies included in the meta-analysis

\begin{tabular}{|c|c|c|c|c|c|c|c|c|c|c|c|}
\hline Study & Year & $\begin{array}{l}\text { Study } \\
\text { design }\end{array}$ & Country & $\begin{array}{l}\text { Study } \\
\text { period }\end{array}$ & $\begin{array}{l}\text { No (malel } \\
\text { female) }\end{array}$ & $\begin{array}{l}\text { Mean age } \pm \text { SD } \\
\text { (years) }\end{array}$ & $\begin{array}{l}\text { Survival } \\
\text { type }\end{array}$ & CV & Treatment & Stage & HR \\
\hline $\begin{array}{l}\text { Feng } \\
\text { et } \mathrm{al}^{23}\end{array}$ & 2014 & $\mathrm{R}$ & $\begin{array}{l}\text { People's Republic } \\
\text { of China }\end{array}$ & $2005-2008$ & $\begin{array}{l}483 \\
(4 I I / 72)\end{array}$ & $59.1 \pm 8.0(34-80)$ & OS & 3.5 & Surgery & $\mathrm{NR}^{*}$ & $M / U$ \\
\hline $\begin{array}{l}\text { Hirahara } \\
\text { et al }{ }^{18}\end{array}$ & 2015 & $\mathrm{R}$ & Japan & $2006-2014$ & $\begin{array}{l}|4| \\
(127 / \mid 4)\end{array}$ & $\begin{array}{l}\text { NR }(\geq 70, n=46 ; \\
<70, n=95)\end{array}$ & OS & 2.5 & Surgery & I-III & U \\
\hline $\begin{array}{l}\text { Han } \\
\text { et } \mathrm{al}^{24}\end{array}$ & 2015 & $\mathrm{R}$ & $\begin{array}{l}\text { People's Republic } \\
\text { of China }\end{array}$ & 2007-2008 & $\begin{array}{l}218 \\
(|77 / 4|)\end{array}$ & $60.5(32-84)$ & OS, DFS & 2.6 & Mix & I-III & $M / U$ \\
\hline $\begin{array}{l}\text { Shao } \\
\text { et } \mathrm{al}^{6}\end{array}$ & 2015 & $\mathrm{R}$ & $\begin{array}{l}\text { People's Republic } \\
\text { of China }\end{array}$ & $2002-2012$ & $\begin{array}{l}633 \\
(484 / 149)\end{array}$ & $60(37-83)$ & OS & 1.7 & Surgery & I-III & $M / U$ \\
\hline $\begin{array}{l}\mathrm{He} \\
\text { et } \mathrm{al}^{17}\end{array}$ & 2016 & NR & $\begin{array}{l}\text { People's Republic } \\
\text { of China }\end{array}$ & $2000-2010$ & $\begin{array}{l}317 \\
(268 / 49)\end{array}$ & $60(37-77)$ & OS, DFS & 3.3 & Mix & I-IV & $M$ \\
\hline $\begin{array}{l}\text { Ji } \\
\text { et } \mathrm{al}^{22}\end{array}$ & 2016 & $\mathrm{R}$ & $\begin{array}{l}\text { People's Republic } \\
\text { of China }\end{array}$ & $2009-2012$ & $\begin{array}{l}41 \\
(38 / 3)\end{array}$ & $56.6 \pm 7.2$ & OS, PFS & 5 & Mix & I-III & $M / U$ \\
\hline $\begin{array}{l}\text { Kosumi } \\
\text { et } \mathrm{al}^{21}\end{array}$ & 2016 & $\mathrm{R}$ & Japan & $2005-2011$ & $\begin{array}{l}283 \\
(248 / 35)\end{array}$ & $\begin{array}{l}\text { NR }(\geq 65, \mathrm{n}=165 \\
<65, \mathrm{n}=1 \mid 8)\end{array}$ & OS & 1.94 & Mix & I-IV & $M / U$ \\
\hline $\begin{array}{l}\text { Toyokawa } \\
\text { et } \mathrm{al}^{7}\end{array}$ & 2016 & $\mathrm{R}$ & Japan & $2000-2014$ & $\begin{array}{l}185 \\
(152 / 33)\end{array}$ & $64(59-70)$ & OS & 3.612 & Mix & I-IV & $M$ \\
\hline $\begin{array}{l}\text { Zhang } \\
\text { et } \mathrm{al}^{20}\end{array}$ & 2016 & $\mathrm{R}$ & $\begin{array}{l}\text { People's Republic } \\
\text { of China }\end{array}$ & 2006-20II & $\begin{array}{l}212 \\
(166 / 46)\end{array}$ & $60(37-81)$ & OS, PFS & 3 & Chemoradiotherapy & $N R * *$ & $M$ \\
\hline
\end{tabular}

Notes: R: retrospective study; M: HR from multivariate analysis; U: HR from univariate analysis; Mix: mixed treatment with at least two anticancer methods including chemotherapy, surgery, radiotherapy, or chemoradiotherapy. *No patients had metastasis. **A few patients had metastasis.

Abbreviations: CV, cutoff value; HR, hazard ratio; OS, overall survival; NR, not reported; DFS, disease-free survival; PFS, progression-free survival; SD, standard deviation. 


\begin{tabular}{|c|c|c|}
\hline \multicolumn{2}{|r|}{ ES $(95 \% \mathrm{Cl})$} & \multirow{2}{*}{$\frac{\text { Weight (\%) }}{19.18}$} \\
\hline Feng et $\mathrm{al}^{23}$ & $1.34(1.01,1.77)$ & \\
\hline Ji et $a^{22}$ & $3.50(1.18,10.39)$ & 1.25 \\
\hline Hirahara et al ${ }^{18}$ & $1.16(0.63,2.16)$ & 3.85 \\
\hline Han et $\mathrm{al}^{24}$ & $1.13(0.76,1.68)$ & 9.38 \\
\hline Kosumi et $\mathrm{al}^{21}$ & $1.84(1.16,2.91)$ & 7.01 \\
\hline Shao et $a^{6}$ & $1.26(0.99,1.61)$ & 25.14 \\
\hline He et $\mathrm{al}^{17}$ & $1.37(1.02,1.84)$ & 16.69 \\
\hline Toyokawa et $\mathrm{al}^{7}$ & $1.19(0.63,2.27)$ & 3.56 \\
\hline Zhang et $\mathrm{al}^{20}$ & $1.19(0.86,1.65)$ & 13.94 \\
\hline Overall $\left(I^{2}=0.0 \%, P=0.593\right)$ & $1.31(1.16,1.48)$ & 100 \\
\hline 0.1 & & \\
\hline
\end{tabular}

Figure 2 Meta-analysis of the association between NLR and OS in ESCC. Results are presented as individual and pooled HR, and 95\% Cl.

Abbreviations: NLR, neutrophil-to-lymphocyte ratio; OS, overall survival; ESCC, esophageal squamous cell carcinoma; $\mathrm{HR}$, hazard ratio; $\mathrm{Cl}$, confidence interval; $\mathrm{ES}$, effect size.

HR $=1.314 ; 95 \%$ CI, 1.164-1.484; $P<0.001$; Figure 2), and there was no significant heterogeneity $\left(I^{2}=0 \%, P_{\mathrm{h}}=0.593\right.$; Table 2). Subgroup analysis by cutoff values revealed that the combined HR was $1.345(95 \% \mathrm{CI}, 1.098-1.647 ; P=0.004$; $\left.I^{2}=12.2 \%, P_{\mathrm{h}}=0.32\right)$ for cutoff value $\leq 2.5$, whereas the HR was $1.297\left(95 \% \mathrm{CI}, 1.114-1.51 ; P=0.001 ; I^{2}=0 \%, P_{\mathrm{h}}=0.531\right)$ for patients with a cutoff value $>2.5$. Subgroup analysis by sample size revealed that the combined HR was $1.316(95 \%$ CI, 1.083-1.598; $\left.P=0.006 ; I^{2}=20.4 \%, P_{\mathrm{h}}=0.28\right)$ for sample size $<300$ and 1.313 (95\% CI, 1.124-1.534; $P=0.001$; $\left.I^{2}=0 \%, P_{\mathrm{h}}=0.905\right)$ for studies with sample size $>300$. Subgroup analysis according to treatment method showed that the combined HR was 1.283 (95\% CI, 1.077-1.528; $P=0.005$ ) for patients undergoing surgery alone and 1.404

Table 2 Summary of the meta-analysis results

\begin{tabular}{|c|c|c|c|c|c|c|c|}
\hline \multirow[t]{2}{*}{ Factor } & \multirow{2}{*}{$\begin{array}{l}\text { No of } \\
\text { studies }\end{array}$} & \multirow{2}{*}{$\begin{array}{l}\text { No of } \\
\text { patients }\end{array}$} & \multirow{2}{*}{$\begin{array}{l}\text { Effects } \\
\text { model }\end{array}$} & \multirow[t]{2}{*}{ HR (95\% Cl) } & \multirow[t]{2}{*}{$P$-value } & \multicolumn{2}{|c|}{ Heterogeneity } \\
\hline & & & & & & $I^{2}(\%)$ & $\boldsymbol{P}_{\mathrm{h}}$ \\
\hline \multicolumn{8}{|l|}{ os } \\
\hline Overall & 9 & 2,513 & Fixed & $1.314(1.164-1.484)$ & $<0.001$ & 0 & 0.593 \\
\hline \multicolumn{8}{|l|}{ Country } \\
\hline People's Republic & 6 & 609 & Fixed & I.29I (I.132-I.472) & $<0.001$ & 0 & 0.533 \\
\hline \multicolumn{8}{|l|}{ of China } \\
\hline Japan & 3 & 1,904 & Fixed & $1.463(1.063-2.015)$ & 0.02 & 0 & 0.394 \\
\hline \multicolumn{8}{|l|}{ Treatment } \\
\hline Surgery & 3 & 1,257 & Fixed & I.283 (I.077-1.528) & 0.005 & 0 & 0.902 \\
\hline Mixed & 5 & $\mathrm{I}, 044$ & Fixed & 1.404 (I.152-I.7I) & 0.001 & 26.4 & 0.245 \\
\hline \multicolumn{8}{|l|}{ Cutoff value } \\
\hline$\leq 2.5$ & 3 & $\mathrm{I}, 057$ & Fixed & I.345 (I.098-1.647) & 0.004 & 12.2 & 0.32 \\
\hline$>2.5$ & 6 & $\mathrm{I}, 456$ & Fixed & $1.297(1.114-1.51)$ & 0.001 & 0 & 0.531 \\
\hline \multicolumn{8}{|l|}{ Sample size } \\
\hline$<300$ & 6 & $\mathrm{I}, 080$ & Fixed & $1.316(1.083-1.598)$ & 0.006 & 20.4 & 0.28 \\
\hline$>300$ & 3 & $\mathrm{I}, 433$ & Fixed & $1.313(1.124-1.534)$ & 0.001 & 0 & 0.905 \\
\hline \multicolumn{8}{|l|}{ Survival analysis } \\
\hline Univariate & 6 & 1,799 & Fixed & 1.335 (I.I49-I.55) & $<0.001$ & 16 & $0.31 I$ \\
\hline Multivariate & 8 & 2,372 & Fixed & $1.321(1.167-1.495)$ & $<0.001$ & 0 & 0.502 \\
\hline \multicolumn{8}{|l|}{ DFS } \\
\hline Overall & 2 & 525 & Fixed & $1.268(1.01-1.592)$ & 0.041 & 0 & 0.845 \\
\hline \multicolumn{8}{|l|}{ PFS } \\
\hline Overall & 2 & 253 & Fixed & $1.221(0.9-1.655)$ & 0.2 & 0 & 0.484 \\
\hline
\end{tabular}

Note: $P_{h}: P$-value of $Q$ test for heterogeneity.

Abbreviations: $\mathrm{HR}$, hazard ratio; $\mathrm{Cl}$, confidence interval; OS, overall survival; DFS, disease-free survival; PFS, progression-free survival; No, number. 
Table 3 Meta-analysis of the association between NLR and clinicopathologic features of ESCC

\begin{tabular}{|c|c|c|c|c|c|c|c|}
\hline \multirow[t]{2}{*}{ Variable } & \multirow{2}{*}{$\begin{array}{l}\text { No of } \\
\text { studies }\end{array}$} & \multirow{2}{*}{$\begin{array}{l}\text { No of } \\
\text { patients }\end{array}$} & \multirow[t]{2}{*}{ OR (95\% Cl) } & \multirow[t]{2}{*}{$P$-value } & \multicolumn{2}{|c|}{ Heterogeneity } & \multirow{2}{*}{$\begin{array}{l}\text { Publication } \\
\text { bias Begg's } P\end{array}$} \\
\hline & & & & & $I^{2}(\%)$ & $\boldsymbol{P}_{\mathrm{h}}$ & \\
\hline TNM stage (III-IV vs I-II) & 3 & 576 & $1.578(\mathrm{I} .1 \mathrm{I}-2.243)$ & 0.011 & 0 & 0.623 & I \\
\hline Tumor differentiation (poor vs moderate/high) & 4 & 1,059 & $1.51(1.106-2.061)$ & 0.01 & 35.1 & 0.202 & 0.734 \\
\hline Depth of invasion (T3-T4 vs TI-T2) & 4 & 954 & $2.742(1.997-3.765)$ & $<0.001$ & 14.9 & 0.318 & 0.734 \\
\hline Tumor size $(>3 \mathrm{~cm}$ vs $<3 \mathrm{~cm})$ & 3 & 1,018 & $2.825(1.675-4.764)$ & $<0.001$ & 62.9 & 0.067 & I \\
\hline Lymph node metastasis (yes vs no) & 5 & I,27। & $1.424(0.862-2.355)$ & 0.168 & 68.9 & 0.012 & 0.806 \\
\hline Vascular invasion (yes vs no) & 2 & 524 & $1.383(0.859-2.228)$ & 0.182 & 0 & 0.336 & 1 \\
\hline
\end{tabular}

Note: $P_{h}: P$-value of $Q$ test for heterogeneity.

Abbreviations: NLR, neutrophil-to-lymphocyte ratio; ESCC, esophageal squamous cell carcinoma; OR, odds ratio; $\mathrm{Cl}$, confidence interval; TNM, tumor node metastasis; No, number.

(95\% CI, $1.152-1.71 ; P=0.001)$ for patients with multimodal treatment. No significant heterogeneity was observed (Table 2). Subgroup analyses conducted by country and survival analyses (univariate and multivariate analysis) are also shown in Table 2.

Our study also examined the impact of NLR on PFS and DFS. Two cohorts revealed that elevated NLR was notably correlated with poorer DFS (HR $=1.268 ; 95 \% \mathrm{CI}, 1.01-1.592$; $P=0.041)$ with no heterogeneity $\left(I^{2}=0 \%, P_{\mathrm{h}}=0.845\right)$. However, the pooled data of another two cohorts, also using a fixed-effects model, revealed that NLR had no prognostic role in PFS for ESCC ( $\mathrm{HR}=1.221 ; 95 \% \mathrm{CI}, 0.9-1.655 ; P=0.2$; $\left.I^{2}=0 \%, P_{\mathrm{h}}=0.484\right)$ (Table 2).

\section{NLR and clinicopathologic parameters of ESCC}

We also examined the relationship between NLR and clinicopathologic characteristics. Five studies ${ }^{17,20,22-24}$ reported the association of NLR with clinicopathologic features such as lymph node metastasis, tumor node metastasis stage, tumor differentiation, depth of tumor invasion, tumor size, and vascular invasion. Our results showed that higher NLR was positively associated with depth of tumor invasion $(n=4$; OR $=2.742 ; 95 \%$ CI, 1.997-3.765; $P<0.001)$, tumor size ( $\mathrm{n}=3$; OR $=2.825 ; 95 \% \mathrm{CI}, 1.675-4.764 ; P<0.001)$, clinical stage $(\mathrm{n}=3 ; \mathrm{OR}=1.578 ; 95 \% \mathrm{CI}, 1.11-2.243 ; P=0.011)$, and poor differentiation $(\mathrm{n}=4$; OR $=1.51 ; 95 \% \mathrm{CI}, 1.106-2.061$; $P=0.01$ ). Elevated NLR was not correlated with lymph node metastasis or vascular invasion (Table 3 ).

\section{Publication bias and sensitivity analysis}

We used the Begg's test and Egger's test to evaluate publication bias. The results revealed that there was no significant publication bias in OS ( $P=0.348$ for Begg's test and $P=0.225$ for Egger's test respectively). Furthermore, there was no significant bias in the analysis of the relationship between NLR and clinicopathologic characteristics (Table 3). The results of sensitivity analysis demonstrated that the combined HR

\section{A}
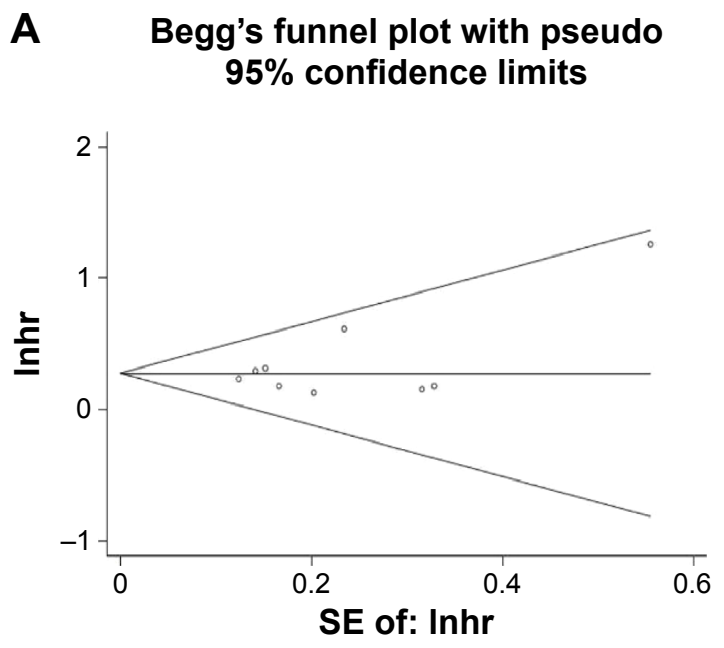

B

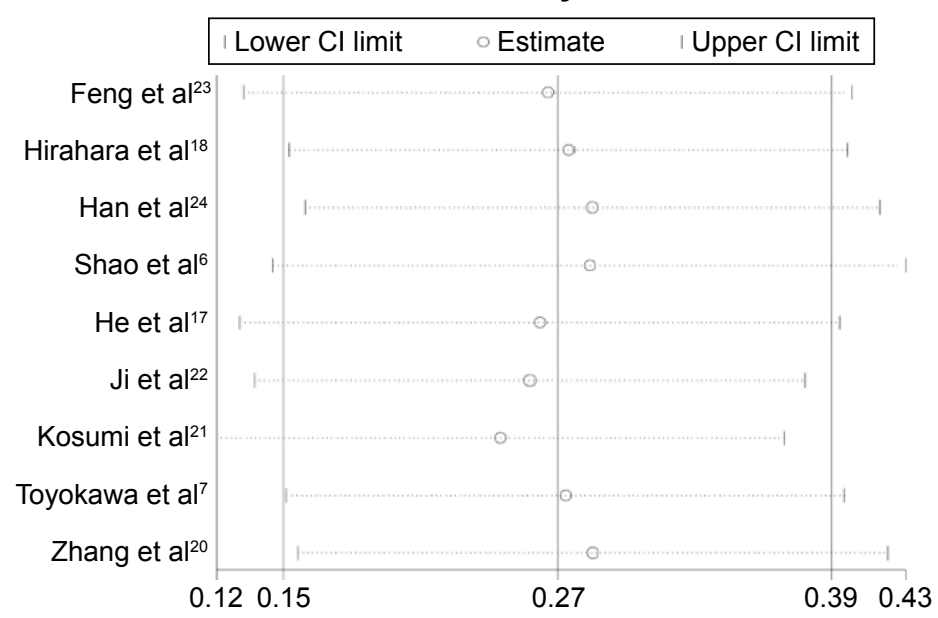

Figure 3 (A) Begg's funnel plot for the assessment of potential publication bias. (B) Sensitivity analysis of the relationship between NLR and OS. Abbreviations: NLR, neutrophil-to-lymphocyte ratio; OS, overall survival; SE, standard error; Inhr, natural logarithm of hazard ratio; $\mathrm{Cl}$, confidence interval. 
for OS was not markedly changed, indicating the reliability of our results (Figure $3 \mathrm{~B}$ ).

\section{Discussion}

Results of this meta-analysis of nine studies with 2,513 ESCC patients suggested that elevated NLR significantly correlated with poor OS (pooled HR =1.314; 95\% CI, 1.164-1.484; $P<0.001)$ in patients with ESCC. Subgroup analyses also showed that high NLR was correlated with poor OS in ESCC for different treatment methods and different countries. Elevated NLR was associated with poor DFS, but had no prognostic role for PFS. In addition, elevated NLR was correlated with large tumor size, deep depth of tumor invasion, late stage, and poor differentiation in ESCC patients. Overall, these findings suggest that NLR might be used as an effective serum biomarker in the prognosis of ESCC.

An increasing number of studies have proved that inflammation plays a critical role in cancer progression and prognosis. Control and regulation of the inflammatory response is a potential therapeutic strategy in cancer treatment that may provide an opportunity to improve patient outcome..$^{25,26}$ Recently, the associations of inflammation-based markers with the prognosis of various cancers have been actively explored. ${ }^{14-16}$ The combined index of NLR, which could partially reflect the inflammatory status of patients, is a promising marker for assessing the systemic inflammatory changes. Various studies have proved that an elevated NLR is positively correlated with poor prognosis in many cancer types. ${ }^{15,27,28}$ Accumulating data have demonstrated that lymphocytes can prevent tumor development from immune compartments and that lymphocytes express recombined antigen receptors to regulate the immunosurveillance process. ${ }^{29}$ Existing studies show that $\mathrm{CD}^{+}$and $\mathrm{CD}^{+}$ T lymphocytes play a critical role in cell-mediated immunity. Tumor-infiltrating $\mathrm{CD}^{+}$and $\mathrm{CD}^{+} \mathrm{T}$ lymphocytes have been proved to have antitumor activity and could be an indicator to predict prognosis in many cancer patients. ${ }^{30-32}$ In contrast, neutrophils have been recognized as an important element in tumor progression. Bidirectional cross talk between neutrophils and tumor cells results in changes that eventually lead to tumor-infiltrating (associated) neutrophils (TANs) equipped with various tumor-promoting features. Growing evidence indicates that TANs might be associated with a poor prognosis through the promotion of angiogenesis, cell mobility, and migration. ${ }^{33-35}$ Thus, a high value of NLR in the serum is a valuable index to evaluate the level of inflammation and is ultimately correlated with prognosis. Importantly, the NLR is easy to measure at very low cost. Together, these characteristic features suggest that NLR might be a useful tool for clinicians when performing clinical therapy and evaluating the outcomes.

Two previous meta-analyses have reported the relationship between NLR and survival in esophageal cancer; ${ }^{36,37}$ however, the prognostic role of NLR in ESCC required more investigation. To our knowledge, our research is the first to identify the prognostic and clinicopathologic significance of peripheral blood NLR in ESCC. However, this meta-analysis has some limitations. First, all studies included in this metaanalysis were from Asian countries. It is well known that the pattern of pathology of the esophageal cancer is quite different between Western and Asian countries; adenocarcinoma of the esophagus and the gastroesophageal junction is prevalent in the West, whereas ESCC is more prevalent in Asia. ${ }^{1,4}$ Although some articles have reported the relationship between esophageal cancer and NLR in Western countries, including both esophageal adenocarcinoma and squamous cell carcinoma, ${ }^{38,39}$ we failed to get sufficient data for the ESCC subgroup, and these studies were excluded from our analysis. Therefore, our results may have limited value in other geographic regions. Second, the cutoff values of NLR varied among studies, which may lead to heterogeneity. In addition, there may have been a lack of uniformity. Third, some articles evaluated the relationship between NLR and cancer-specific survival, but not OS. ${ }^{40,41} \mathrm{We}$ did not include these articles because of the small numbers involved. Fourth, all of the studies enrolled in our meta-analysis were retrospective and published in English. Therefore, the pooled HR estimates should be interpreted with caution.

\section{Conclusion}

In summary, we found that a high value of NLR might be a negative factor when estimating prognosis of ESCC patients. Furthermore, elevated NLR might be a predictor of deeper tumor invasion, advanced stage, and poor differentiation. Further well-designed and large prospective studies are needed to confirm our results. In addition, additional research should focus on anti-inflammatory interventions for patients with ESCC.

\section{Acknowledgments}

The authors would like to thank Dr Xiang Wang for statistic assistance. Our study was supported by the National Natural Science Foundation of China (No NSFC 81202095).

\section{Disclosure}

The authors report no conflicts of interest in this work.

\section{References}

1. Torre LA, Bray F, Siegel RL, Ferlay J, Lortet-Tieulent J, Jemal A. Global cancer statistics, 2012. CA Cancer J Clin. 2015;65(2):87-108. 
2. Hiyama T, Yoshihara M, Tanaka S, Chayama K. Genetic polymorphisms and esophageal cancer risk. Int J Cancer. 2007;121(8):1643-1658.

3. Wu C, Hu Z, He Z, et al. Genome-wide association study identifies three new susceptibility loci for esophageal squamous-cell carcinoma in Chinese populations. Nat Genet. 2011;43(7):679-684.

4. Lin CS, Chang SC, Wei YH, et al. Prognostic variables in thoracic esophageal squamous cell carcinoma. Ann Thorac Surg. 2009;87(4): 1056-1065.

5. Chen S, Yang X, Feng JF. A novel inflammation-based prognostic score for patients with esophageal squamous cell carcinoma: the c-reactive protein/ prognostic nutritional index ratio. Oncotarget. Epub 2016 Aug 19.

6. Shao Y, Ning Z, Chen J, et al. Prognostic nomogram integrated systemic inflammation score for patients with esophageal squamous cell carcinoma undergoing radical esophagectomy. Sci Rep. 2015;5:18811.

7. Toyokawa T, Kubo N, Tamura T, et al. The pretreatment Controlling Nutritional Status (CONUT) score is an independent prognostic factor in patients with resectable thoracic esophageal squamous cell carcinoma: results from a retrospective study. BMC Cancer. 2016;16:722.

8. Mantovani A, Allavena P, Sica A, Balkwill F. Cancer-related inflammation. Nature. 2008;454(7203):436-444.

9. Grivennikov SI, Greten FR, Karin M. Immunity, inflammation, and cancer. Cell. 2010;140(6):883-899.

10. Elinav E, Nowarski R, Thaiss CA, Hu B, Jin C, Flavell RA. Inflammation-induced cancer: crosstalk between tumours, immune cells and microorganisms. Nat Rev Cancer. 2013;13(11):759-771.

11. Tsilidis KK, Branchini C, Guallar E, Helzlsouer KJ, Erlinger TP, Platz EA. C-reactive protein and colorectal cancer risk: a systematic review of prospective studies. Int J Cancer. 2008;123(5):1133-1140.

12. Guo L, Liu S, Zhang S, et al. C-reactive protein and risk of breast cancer: a systematic review and meta-analysis. Sci Rep. 2015;5:10508.

13. Yin X, Xiao Y, Li F, Qi S, Yin Z, Gao J. Prognostic role of neutrophilto-lymphocyte ratio in prostate cancer: a systematic review and metaanalysis. Medicine (Baltimore). 2016;95(3):e2544.

14. Gu XB, Tian T, Tian XJ, Zhang XJ. Prognostic significance of neutrophilto-lymphocyte ratio in non-small cell lung cancer: a meta-analysis. $S c i$ Rep. 2015;5:12493.

15. Grenader T, Waddell T, Peckitt C, et al. Prognostic value of neutrophilto-lymphocyte ratio in advanced oesophago-gastric cancer: exploratory analysis of the REAL-2 trial. Ann Oncol. 2016;27(4):687-692.

16. Pine JK, Morris E, Hutchins GG, et al. Systemic neutrophil-tolymphocyte ratio in colorectal cancer: the relationship to patient survival, tumour biology and local lymphocytic response to tumour. $\mathrm{Br} J$ Cancer. 2015;113(2):204-211.

17. He YF, Luo HQ, Wang W, et al. Preoperative NLR and PLR in the middle or lower ESCC patients with radical operation. Eur J Cancer Care (Engl). Epub 2016 Mar 7; doi:10.1111/ecc.12445.

18. Hirahara N, Matsubara T, Hayashi H, Takai K, Fujii Y, Tajima Y. Impact of inflammation-based prognostic score on survival after curative thoracoscopic esophagectomy for esophageal cancer. Eur J Surg Oncol. 2015;41(10):1308-1315.

19. Wells GA, Shea B, O'Connell D, et al. The Newcastle-Ottawa Scale (NOS) for assessing the quality of nonrandomised studies in metaanalyses. Available from: http://www.ohri.ca/programs/clinical_epidemiology/oxford.asp. Accessed February 14, 2017.

20. Zhang P, Xi M, Zhao L, et al. Comparison of two inflammation-based prognostic scores in patients with thoracic esophageal cancer undergoing chemoradiotherapy. Int J Clin Exp Med. 2016;9(2):1764-1771.

21. Kosumi K, Baba Y, Ishimoto T, et al. Neutrophil/lymphocyte ratio predicts the prognosis in esophageal squamous cell carcinoma patients. Surg Today. 2016;46(4):405-413.

22. Ji WH, Jiang YL, Ji YL, Li B, Mao WM. Prechemotherapy neutrophil: lymphocyte ratio is superior to the platelet: lymphocyte ratio as a prognostic indicator for locally advanced esophageal squamous cell cancer treated with neoadjuvant chemotherapy. Dis Esophagus. 2016;29(5): 403-411.
23. Feng JF, Huang Y, Chen QX. Preoperative platelet lymphocyte ratio (PLR) is superior to neutrophil lymphocyte ratio (NLR) as a predictive factor in patients with esophageal squamous cell carcinoma. World $J$ Surg Oncol. 2014;12:58.

24. Han LH, Jia YB, Song QX, Wang JB, Wang NN, Cheng YF. Prognostic significance of preoperative lymphocyte-monocyte ratio in patients with resectable esophageal squamous cell carcinoma. Asian Pac J Cancer Prev. 2015;16(6):2245-2250.

25. Diakos CI, Charles KA, McMillan DC, Clarke SJ. Cancer-related inflammation and treatment effectiveness. Lancet Oncol. 2014;15(11): e493-e503.

26. Crusz SM, Balkwill FR. Inflammation and cancer: advances and new agents. Nat Rev Clin Oncol. 2015;12(10):584-596.

27. Hsu JT, Liao CK, Le PH, et al. Prognostic value of the preoperative neutrophil to lymphocyte ratio in resectable gastric cancer. Medicine (Baltimore). 2015;94(39):e1589.

28. Bazzi WM, Tin AL, Sjoberg DD, Bernstein M, Russo P. The prognostic utility of preoperative neutrophil-to-lymphocyte ratio in localized clear cell renal cell carcinoma. Can J Urol. 2016;23(1):8151-8154.

29. Dunn GP, Old LJ, Schreiber RD. The immunobiology of cancer immunosurveillance and immunoediting. Immunity. 2004;21(2):137-148.

30. Sznurkowski JJ, Zawrocki A, Emerich J, Biernat W. Prognostic significance of CD4+ and CD8+ T cell infiltration within cancer cell nests in vulvar squamous cell carcinoma. Int J Gynecol Cancer. 2011;21(4): 717-721.

31. Mahmoud SM, Paish EC, Powe DG, et al. Tumor-infiltrating CD8+ lymphocytes predict clinical outcome in breast cancer. J Clin Oncol. 2011;29(15):1949-1955.

32. Huang Y, Ma C, Zhang Q, et al. CD4+ and CD8+ T cells have opposing roles in breast cancer progression and outcome. Oncotarget. 2015; 6(19): 17462-17478.

33. Moses K, Brandau S. Human neutrophils: their role in cancer and relation to myeloid-derived suppressor cells. Semin Immunol. 2016; 28(2):187-196.

34. Cools-Lartigue J, Spicer J, Najmeh S, Ferri L. Neutrophil extracellular traps in cancer progression. Cell Mol Life Sci. 2014;71(21):4179-4194.

35. Uribe-Querol E, Rosales C. Neutrophils in cancer: two sides of the same coin. J Immunol Res. 2015;2015:983698.

36. Yang X, Huang Y, Feng JF, Liu JS. Prognostic significance of neutrophilto-lymphocyte ratio in esophageal cancer: a meta-analysis. Onco Targets Ther. 2015;8:789-794.

37. Yodying H, Matsuda A, Miyashita M, et al. Prognostic significance of neutrophil-to-lymphocyte ratio and platelet-to-lymphocyte ratio in oncologic outcomes of esophageal cancer: a systematic review and meta-analysis. Ann Surg Oncol. 2016;23(2):646-654.

38. Dutta S, Crumley AB, Fullarton GM, Horgan PG, McMillan DC. Comparison of the prognostic value of tumour- and patient-related factors in patients undergoing potentially curative resection of oesophageal cancer. World J Surg. 2011;35(8):1861-1866.

39. Sharaiha RZ, Halazun KJ, Mirza F, et al. Elevated preoperative neutrophil:lymphocyte ratio as a predictor of postoperative disease recurrence in esophageal cancer. Ann Surg Oncol. 2011;18(12): $3362-3369$.

40. Duan H, Zhang X, Wang FX, et al. Prognostic role of neutrophillymphocyte ratio in operable esophageal squamous cell carcinoma. World J Gastroenterol. 2015;21(18):5591-5597.

41. Xie X, Luo KJ, Hu Y, Wang JY, Chen J. Prognostic value of preoperative platelet-lymphocyte and neutrophil-lymphocyte ratio in patients undergoing surgery for esophageal squamous cell cancer. Dis Esophagus. 2016;29(1):79-85. 


\section{Publish your work in this journal}

OncoTargets and Therapy is an international, peer-reviewed, open access journal focusing on the pathological basis of all cancers, potential targets for therapy and treatment protocols employed to improve the management of cancer patients. The journal also focuses on the impact of management programs and new therapeutic agents and protocols on

patient perspectives such as quality of life, adherence and satisfaction. The manuscript management system is completely online and includes a very quick and fair peer-review system, which is all easy to use. Visit http://www.dovepress.com/testimonials.php to read real quotes from published authors.

Submit your manuscript here: http://www.dovepress.com/oncotargets-and-therapy-journal 